\title{
Antecedents of Perceived Job Commitment among Employees of Local Government in Ilesha Metropolis
}

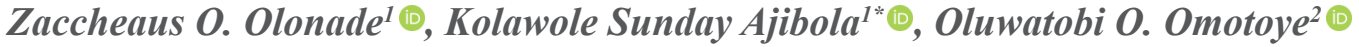

1 Lecturer, Human Resource Development, Faculty of Management Sciences, Osun State University, Okuku Campus, Osun State, Nigeria

2 MSc Student, Employment Relations and Human Resource Management, University of Lagos, Nigeria

* Corresponding Author (ksajibola (a) uniosun.edu.ng)

Received: 02 June, 2020

Revised: 26 July, 2020

Accepted: 18 November, 2020

Published: 15 December, 2020

How to cite this paper: Olonade, Z.O., Ajibola, K.S., \& Omotoye, O.O. (2020). Antecedents of perceived job commitment among employees of local government in Ilesha Metropolis. Quest Journal of Management and Social Sciences, 2(2), 225-239.

Copyright (C) 2020 by authors and Quest Journal of Management and Social Sciences.

This work is licensed under a Creative Commons Attribution-Non Commercial-No Derivatives 4.0 International License.

https://creativecommons.org/

licenses/by-nc-nd/4.0/

\begin{abstract}
Background: Employee commitment primarily focuses on strong bonds between the organization and its employees. It has massive positive effects on organizations. Investigating the combined influence of the assorted psychological factors like work-family conflict, job stress and self-concept on perceived job commitment among employees of Local Government authority is helpful.
\end{abstract}

Objective: The study investigates the antecedents of perceived job commitment among employees of Local Government in Ilesha Metropolis.

Methods: Antecedents of perceived job commitment in this study are work-family conflict, job stress, and self-concept. The study has adopted survey method within a descriptive research design. The objective of the study was to determine the influence of work-family conflict, job stress and self-concept on perceived job commitment. Primary data were used. Data were collected using a structured questionnaire that had five scales in likert scale including personal data. 238 respondents, randomly selected across the three local government areas in Ilesha Metropolis, were used for the study. Only 189 questionnaires were returned, out of which 124 were found to be useful for the study.

Results: Three hypotheses were tested and they revealed that self-concept, workfamily conflict and job stress jointly have a positive and significant impact on perceived job performance. Furthermore, work-family conflict $(\beta=0.173 ; \mathrm{t}=$ $9.119 ; \mathrm{p}<.05)$, job stress $(\beta=1.170 ; \mathrm{t}=7.458 ; \mathrm{p}<.05)$, and self-concept $(\beta=0.064$; $\mathrm{t}=2.444 ; \mathrm{p}<.05)$ independently predicted perceived job commitment to be at $5 \%$ level.

Conclusions: The study has found that factors, like work-family conflict, job stress and self-concept, significantly predict the perceived job commitment among employees of local government in Ilesha Metropolis. The finding of the study implies that the antecedents of employee's job commitment are important variables. Governments, employers of labour, human resource practitioners and psychologists need to give more attention to these variables, especially among local government employees and related workforce, for the increase in employee commitment. The study recommends that governments should adopt welfare approaches in tackling issues around work-family conflict, job stress and selfconcept to improve employee job commitment.

Originality: This article is original and there is no potential conflict of interest.

Keywords: Human Resource, Job Stress, Perceived Job Commitment, SelfConcept, Work-Family Conflict

Paper Type: Research paper

JEL Classification: J24, M10, M12, M31, and O15 


\section{Introduction}

Employee commitment is a "concept that primarily focuses on the strong bond between organization and employees" (Chanda \& Goyal, 2019, p.1). It is the "employees' desire to continue to avail the organization their services towards achievement of its goals" (Izogo, Elom, \& Mpinganjira, 2020, p.1). It has positive effects on organizations (Marchiori \& Henkin, 2004). There are three dimensions of the employee job commitment model as developed by Allen and Meyer (1990). These include the following: affective commitment, continuance commitment, and normative commitment (Izogo, Elom, \& Mpinganjira, 2020). Affective commitment has been identified as a powerful desire to keep up with the membership within the organization. Continuance commitment, on one hand, is the outcome of an individual's decision to stay with an organization. Normative commitment, on the other hand, is defined as the totality of an employee's internalized normative pressures to behave in a manner that is in sync with the organizational goals and interests (Meyer, Stanley, Herscovitch, \& Topolnytsky, 2002). These three dimensions are related to each other (Lizotte, Verdinelli, \& do Nascimento, 2017).

Self-concept has been defined as “a person's perception of himself” (Shavelson, Hubner, \& Stanton, 1976, p.411). It encompasses "perception and reflection and emotional response of individual to perception and reflection" (MacKinnon \& Heise, 2010 in Owens \& Samblanet, 2013, p. 227). In a nutshell, self-concept is a "product of its own objectification, it requires individuals (i.e., subjects, "knowers," or "I's") to stand outside themselves and react to themselves as detached entities of observation (i.e., objects, "the known," or "me's")" (Owens \& Samblanet, 2013, p. 227). The selfconcept is the belief that government employees have about themselves when it involves performing a specific task, which may affect his/her commitment. This behaviour may be related to the self-concept of employees. Self-concept is about the accumulation of information by employees about his/her self, such as beliefs regarding personality traits, physical characteristics, abilities, values, goals, and roles (Purkey, 1998). It is the "totality of an individual's thoughts and feelings having reference to himself as a particular object" (Rosenberg, 1979, p.7).

Job stress is defined as "an individual's response to external stimuli in the" work environment (Deng, Guo, Ma, Yang, \& Tian, 2019). Considering the duty or task of choosing, processing, information searching and dissemination performed by the employees, it is likely that they experience stress. With the aid of role theory, Kahn, Wolfe, Quinn, Snoek, and Rosenthall (1964) have been able to explain the concept of work-family conflict. They proposed that the key determinant of an individual's behaviour is that the expectation of behaviour that others have for him or her.

Various antecedents of employee commitment have been investigated such as motivation (Afshari, 2020), team cognition (Kroll, DeHart-Davis, \& Vogel, 2019), employee participation (Yahaya, 2020; Bryer, 2020), employee training and development (Paillé \& Valéau, 2020), employee job satisfaction, employees' age and employee demographic characteristics (Roy, Weyman, Plugor, \& Nolan, 2020), style management/leadership (Tuffour, Gali, \& Tuffour, 2019; Abasilim, Gberevbie, \& Osibanjo, 2019), job security (Hur, \& Perry, 2019), employee productivity employee performance, and managerial support (Khalid, 2020; Wang, Weng (Derek), \& Jiang, 2020).However, none of the reviewed studies haveinvestigated the combined influence of the assorted psychological factors like work-family conflict, job stress and self-concept on perceived job commitment among employees of local government authority in Ilesha Metropolis. To bridge the gap, the current study investigates the antecedents of perceived job commitment among employees of local government in Ilesha Metropolis using these psychological factors as a proxy of the antecedents.

The rest of the article is organized in the following order: literature review, research methodology, result and discussion, conclusion and recommendation and references. 


\section{Review of Literature}

Lambert, Morrow, Hogan, and Vickovic (2020) explored the association between work-family conflict and job involvement among private correctional staff, and have found that work-family conflict had a significantly positive influence on job involvement. Huitt (2004) claims that the link between job performance and personality (including self-concept) is more of a consequence of social aspects of the workplace than of the individual's ability. Huitt stressed that "cognitive ability is more strongly correlated with task performance" and self-concept is "more of a cognition aspect". Hence, it is possible that an employee, who has a high level of employee self-concept, may exhibit good job performance in jobs requiring mental skills. Similarly, Zain and Setiawati (2019) observed the influence of workfamily conflict and job satisfaction on medical employees' performances through organizational commitment in Indonesia. They have reported that work-family conflict had no significant influence on organizational commitment. In another study, Sinha (2004) expressed that personality (including self-concept) does not have a high impact on an employee's job performance, in and of itself. Another research examined the link among three aspects: self-concept traits, entrepreneurial orientation and firm performance. It reported that self-concept was positively associated with the performance of the staff (Porn, 2006).

Empirical research has shown that work-family conflict (WFC) is a recurring decimal among employees in organizations (Durand, Burrel, Stetz, \& Castro, 2003; Centre for American Progress, 2010). Individual self-identification, through the process of social roles for many other people, identifies the work-family roles as vital and important self-relevant roles. Empirical research has found that family and work job demands are always incompatible and conflictual (Fub, Nubling, Hasselhorn, Schwappach, \& Rieger, 2008).

Similarly, Ajibola (2015) investigated the influence of time management on employees' commitment to the organization, among 154 employees of the University of Lagos. The study has discovered that time management identifies organizational commitment among the staff of the university. Cao, Liu, Wu, Zhao, and Jiang (2020) conducted a study of 137 construction company employees in China. The study employed a structured questionnaire to collect data from the 137 professionals working in the construction sector. The data collected for the study were analysed using structural equation modeling (SEM). The study reported that work-family conflict interferes with work negatively and it also affects organizational commitment significantly (Cao, Liu, Wu, Zhao, \& Jiang, 2020). In Nigeria, Balogun and Afolabi (2019) researched the moderating roles of job demands and resources on the relationship between work engagement and work-family conflict among 156 working mothers. They have found that work engagement is positively related to work-family conflict. Also, job demands moderate the link between work engagement and work-family conflict.

Another research which investigated the experience of stress and coping mechanism among 342 police officers in South Western Nigeria found that work stress had a negative impact on the job commitment of the officers. The work adopted a descriptive research design and a multistage sampling technique to draw the sample for the research (John-Akinola, Ajayi, \& Oluwasanu, 2020). Odor (2019) worked on work-related stress and employee commitment among 110 teaching staff of Delta State Polytechnic, Nigeria. The study used regression analysis. The study has found work stress to negatively and significantly affect employee commitment.

Nwekpa, Offor, and Ezezue (2020) studied work schedule flexibility and employee commitment: a study of Nigerian Breweries, Ama, Enugu, Nigeria. The study sampled 283 respondents from Nigerian Brewery. A regression analysis was used in the study. The findings of the study indicated that there is a significant relationship between job sharing and continuance commitment. It has also found that compressed work significantly influences normative commitment (Nwekpa, Offor, \& Ezezue, 2020). 
The bi-directional nature of work and family conflict influences that employee job performance because of its power to lower performance (Greenhaus, 2010). Studies also revealed that certain factors, that produce extensive work-family conflict within the environment, are pressures such as extensive, irregular, inflexible work hours, extensive travel, interpersonal conflict at home; career transitions; and unsupportive superior or organization. Pressures within the family environment: the presence of young children, primary responsibility for children, eldercare responsibilities, interpersonal conflict within the family unit, and unsupportive relations (Boyar, Maertz, Pearson, \& Keough, 2003; Payne \& Castro, 2003).

Four work environmental factors that trigger work-family role conflicts have been identified as highstrain jobs, active jobs, low-strain (relaxed) jobs, and passive jobs (Lindstrom, 2005; Park, 2007). Furthermore, the works of Palmer, Cooper, and Thomas (2004) and Hansen (2008) focus on the relationship between job induced stress and job performance. Thus, local government employees can have job stress induced by family demands, which could result in low job performance.

\section{Work-family Conflict}

The work-family conflict is taken into account for the individual's role conflict, when a person has dual roles as a working father or a working mother (Dubrin, 1997). Within the field of literature, workfamily conflict is sometimes specified as "a kind of inter-role conflict within which the role pressures of the work and family domains are mutually incompatible in some respect" (Greenhaus \& Beutell, 1985, p. 81). The condition is mostly tested within two dimensions, defined as work-family conflict and family-work conflict and these conditions are employed within the same substance. The primary dimension, which is work-family conflict, occurs owing to the deprivation of the responsibilities of a person when he/she cannot do the duties associated with the household life.

The secondary dimension, which is defined as the family-work conflict, occurs when a person cannot do his/her duties associated with work life. Whether or not the triggering factors differentiate, workfamily or family-work conflicts stand for the essentials associated with the work and roles of the family. Researches prove that there's a considerable correlation between these roles (Altura, Rao, \& Virick, 2020). The explanations behind the work-family conflict are stated as; long and unsteady working hours, overtime working, autonomy status, the scale of the organization, low wages, negative attitudes of management, work relations, promotion, expectations of the family, health status, number of kids, age, income and employee performance (Aboobaker \& Edward, 2019; Chrisangika-Perera \& Kailasapathy, 2020).

Employees' work-family conflicts differ due to demographic factors. Researches, that mainly target gender differences, prove that the extent of conflict amongst women is way above men (Haines, Bilodeau, Demers, Marchand, Beauregard, Durand, \& Blanc, 2019; Kaufman, \& Taniguchi, 2019). Furthermore, various family specialties like the number of kids and their ages, the dearth of support amongst couples in way of life and the dearth of distributing the responsibilities of kid care are stated to be some of the other reasons for work-family conflict (Dolson \& Deemer, 2020; Badawy \& Schieman, 2020).

\section{Job Stress}

Stress can influence the lives of people in unexpected ways. In other words, demands that come from both employees' work and their families can exceed the stamina of a person that leaves the employee with increased tension (Lee \& Jang, 2020). High levels of stress can cause negative consequences like absenteeism, industrial accidents and injuries. Research studies underline the importance of the relations between work-family conflict and work stress (Vickovic \& Morrow, 2020). Succinctly, these problems occur when the family and work load restricts the employee's time enough to make him/her unable to fulfill duties. Some researchers have found positive one-sided and two-sided correlations between job 
stress and work-family life, along with work-family life itself (Narisada, 2020; Chrisangika-Perera \& Kailasapathy, 2020).

\section{Self-Concept}

Self-concept is one's beliefs about one's self and his/her role in society. The image of such a belief manifests as a mirror of the level of communication the individual has with his/her environment. In other words, self-concept is portrayed by the individual's actions. Self-concept plays an important role in the lives of employees at the workplace; hence there is a need to understand the factors that determine its formation. In the view of Tripp (2003), self-concept is not in-born. Furthermore, the perception and the image that others have of an individual; individual's personal experiences; self-evaluation cum the expectations that others simply have of an individual; the roles an individual performs; their gender, culture and the technological messages an individual internalizes, play important roles in developing the individual's self-concept (Gamble \& Gamble, 2002).

\section{Perceived Job Commitment}

The fact that people have jobs and also the need for these jobs for themselves and their families is obvious, but the way these people feel about their work is sometimes thought of at a later stage. The degree of happiness about their position in a company may be a matter of countless variables, which are too many to be considered during this research. This research focuses on the commitment of an employee and also the role a corporation plays in establishing this. Commitment of an employee in a corporate environment usually is associated with the term "personal commitment to their job" during this case. Commitment to the organization normally consists of three components. According to Allen and Meyer (1990), the three components are affective, continuance and normative commitments. First, there is the affective commitment, which is concerned with how an individual feels about the organization they are working for (Ellis \& Dick, 2003). Continuance commitment is the extent to which an individual perceives the organization desirable or undesirable to depart from it (Ellis \& Dick, 2003). The normative commitment deals with the moral orientation or sense of responsibility or obligation of an individual to an organization. These components are all a part of the commitment of an employee to a company but are independent, which can indicate when an individual is effectively dedicated to their organization. This does not need to be similar for normative or continuance commitment.

From the literature review, it can be summarized that most of the previous studies on job stress, selfconcept, WFC on perceived employee commitment have been conducted in a developed economy such as the one conducted by Zain and Setiawati (2019) in Indonesia, Cao, Liu, Wu, Zhao, and Jiang (2020) in China, with little of such in Nigeria. Researches on perceived job commitment are scanty. Most of the researches focus on other constructs. For instance, Balogun and Afolabi (2019) worked on the moderating roles of job demands and resources on the relationship between work engagement and work-family conflict among 156 working mothers. Also, Odor (2019) worked on work-related stress and employee commitment among 110 teaching staff of Delta State Polytechnic, Nigeria. John-Akinola, Ajayi, and Oluwasanu (2020) investigated the experience of stress and coping mechanism among 342 Police Officers in South Western Nigeria (John-Akinola, Ajayi, \& Oluwasanu, 2020). Similarly, Nwekpa, Offor, and Ezezue (2020) studied work schedule flexibility and employee commitment: a study of Nigerian Breweries, Ama, Enugu, Nigeria. This constituted a literature gap. Also, no previous studies used job stress, self-concept, WFC to proxy the antecedents of perceived employee commitment. 


\section{Research Method}

\section{Theoretical Framework}

The study was guided by Erikson's theory, propounded by Erikson (1959). According to Erikson (1959), a human being passes through eight stages in life from infanthood to late adulthood. In his treatise, he opines that each stage presents different challenges which the individual will confront, master, and develop the schemes to manipulate it. If the individual can succeed at any of the stages, it becomes a building block for the next stage. If the challenges of stages could not be completed, they could also be expected to reappear as problems within the future. However, mastery of a stage isn't required to advance to the consecutive stages. Erikson's 8-stage theory characterizes an individual advancing through the life stages as a function of negotiating with his or her biological forces, and socio-cultural forces. Successful resolution of the stage(s) enhances the development of the ego of the individual. These involve establishing a way of trust. In others, it will help in developing a way of identity in society and help the consecutive generation steel themselves against the longer term. Erikson extends on Freudian thoughts by specializing in the adaptive and inventive characteristics of the ego and expanding the notion of the stages of personality development to incorporate the complete lifespan. The outcome of this 'maturation timetable' may be a wide and integrated set of life skills and talents that function together within the autonomous individual. However, rather than specializing in sexual development (like Freud), he was inquisitive about how individuals socialize and the way this affects their sense of self. Like Freud, Erikson assumes that a crisis occurs at each stage of development.

To Erikson (1959), these crises are psychosocial because they involve the psychological needs of the individual conflicting with the wants of society (i.e. social). In line with the speculation, successful completion of every stage leads to a healthy personality and also the acquisition of basic virtues. Basic virtues are characteristic strengths which the ego can use to resolve subsequent crises. Failure to complete a stage may result in a much-reduced ability to finish further stages. And this could lead to the emergence of a more unhealthy personality and sense of self. These stages, however, are often resolved successfully later. Erikson's' theory has been criticized for its vagueness about the causes of development. Critics have queried the theory to explain the experiences an individual must have to successfully resolve various psychosocial conflicts. They also ask about how such individuals would navigate from one stage to the other of the 8 stages? It has been argued that the speculation doesn't have a universal mechanism for crisis resolution. The above criticisms notwithstanding, the theory had been adjudged to strengthen its ability to tie together important psychosocial development across the complete lifespan. Although support for Erikson's stages of personality development exists, critics of his theory do provide evidence, suggesting a scarcity of discrete stages of personality development (Schultz \& Schultz, 2017).

\section{Research Design, Study Area, and Sample}

The survey research design was adopted for the study. The target population for the study comprises all employees of the Local Government in Ilesha Metropolis, Nigeria. Ilesha Metropolis is in Osun State, South-West Nigeria. It is a popular major town of Ijesha land.

The Ijeshas are known as Osomaalo. "Of all the many sub-tribes that make up the Yoruba nation of Southwest, Nigeria, and a substantial part of Benin Republic, the Ijeshas were renowned in the past for their great success in commerce and they occupy a place in Yoruba folklore. They are known as shylocks because of their shrewdness in business practice, the Ijeshas were notorious for using force to collect their money from debtors in the past, but now this is no more in vogue" (Abiodun, 2013).

The population of the study and the sample drawn from each local government area are presented in Table 1. Furthermore, Yamane (1967) sample determination formula $\left(n=N /\left(1+N(e)^{2}\right)\right.$ was used to determine the sample size with $\mathrm{N}=475, \mathrm{e}=0.05$. The sample size for the study was 218 respondents. A simple random sampling technique was used as the method of distribution of the questionnaire. 
Table 1: Employees and Employees Sampled by their local governments

\begin{tabular}{clcc}
\hline S.N. & \multicolumn{1}{c}{ LOCAL GOVERNMENT } & POPULATION & SAMPLE \\
\hline 1. & Ilesha West Local Government & 155 & 71 \\
2. & Ilesha West Central Local Government & 158 & 73 \\
3. & Ilesha East Local Government & 162 & 74 \\
& Total & $\mathbf{4 7 5}$ & $\mathbf{2 1 8}$ \\
\hline
\end{tabular}

The response rate was $86.7 \%$, which was considered okay for the study. However, only $56.9 \%$ of the returned questionnaires were found useful for the analysis. Scholars differ on the acceptable benchmark for the response rate, some believe that a 50\% response rate is okay for analysis while some averred that there are no absolute response rates (Babbie, 2016). Given the foregone, the response rate for this study was considered alright for analysis.

Table 2: Response Rate

\begin{tabular}{lcc}
\hline Response & Total & Percentage \\
\hline Returned - used for the analysis & 124 & 56.9 \\
Returned - not useable (incomplete) & 65 & 29.8 \\
Unreturned & 29 & 13.3 \\
Total & 218 & 100 \\
\hline
\end{tabular}

\section{Questionnaire Administration and Data Analysis}

The study used a structured questionnaire as a data collection instrument. The questionnaire consisted of thirty (30) questions in which section 'A' contained socio-demographic information, section 'B' information on Self-concept scale (SCS) developed by Stake (1994), section 'C' was on work-family conflict scale (WFCS) that was adapted from Durand (2003), section 'D' had an adapted Job Stress Scale (JSS) that was developed by Parker and Decotiis (1983). Section E contained information on the Perceived Job Commitment Scale (PJC), developed and validated by Meyer and Allen (1997). The respondents were asked to rate the statements on Likert-type scale from Strongly Agree $(\mathrm{SA})=5$, Agree $(A)=4$, Undecided $(U)=3$, Disagree $(D)=2$, and Strongly Disagree $(S D)=1$. A total of 218 copies of questionnaires were administered, out of which 189 copies were returned, from which 124 copies of the questionnaire were found useful and were fully utilized for the study.

Cronbach's coefficient alpha was computed. Items with Cronbach's coefficient alpha of 0.90 and above were considered as excellent. Items with Cronbach's coefficient alpha of $0.80-0.89$ were seen as very good and Cronbach's coefficient alpha of 0.7 was considered as adequate (Saunders, Lewis, \& Thornhill, 2016). This study adopted Cronbach's coefficient alpha of 0.7 as the benchmark to test for the reliability of the measures in the questionnaire for this study. The reliability coefficients of the SCS, WFCS, JSS, and PJC scales were $0.83,0.86,0.77$, and 0.81 respectively using the Cronbach-alpha method.

The data collection instrument adopted for the study was administered using a drop and pick approach. The data collection took place between May and August 2019. Respondents' consent was obtained before the administration of the research instrument. Data collected through questionnaire were analyzed using SPSS version 21. Hypotheses were tested using linear regression analysis. All the hypotheses were tested at a 0.05 level of significance. 


\section{Data Analysis and Result}

\section{Descriptive Statistics}

\section{Demographic Status}

In descriptive statistics, the demographic analysis was performed and is presented in table 3 . It reveals the distribution of respondents by their demographic characteristics. In the table, $29.0 \%$ of the respondents were male, while $71.0 \%$ of the respondents were female, indicating that the majority of the respondents were female. A record pertaining to the ages of the respondents shows that the majority $(49.2 \%)$ of the respondents were between 41 and 50 years. The results indicate that the majority of the respondents $(79 \%)$ were married. On the educational background of the respondents, the majority $(73.4 \%)$ of the respondents have a Higher National Diploma/B.Sc. This implies that respondents in the study were literate and educated.

Table 3: Analysis of Demographic Information

\begin{tabular}{|c|c|c|c|c|}
\hline S.N. & Variable & Category & Frequency & Percentage \\
\hline \multirow[t]{3}{*}{1.} & Gender & Male & 36 & 29.0 \\
\hline & & Female & 88 & 71.0 \\
\hline & & Total & 124 & 100.0 \\
\hline \multirow[t]{5}{*}{2.} & Age & 20-30 years & 24 & 19.4 \\
\hline & & $31-40$ years & 37 & 29.8 \\
\hline & & $41-50$ years & 61 & 49.2 \\
\hline & & 51 years and above & 2 & 1.6 \\
\hline & & Total & 124 & 100 \\
\hline \multirow[t]{4}{*}{3.} & Marital Status & Single & 20 & 16.1 \\
\hline & & Married & 98 & 79.0 \\
\hline & & Divorced & 6 & 4.8 \\
\hline & & Total & 124 & 100 \\
\hline \multirow[t]{5}{*}{4.} & Educational Qualification & SSCE & 2 & 1.6 \\
\hline & & $\mathrm{OND} / \mathrm{NCE}$ & 31 & 25.0 \\
\hline & & $\mathrm{HND} / \mathrm{BSC}$ & 91 & 73.4 \\
\hline & & MSC/Others & 0 & 0.0 \\
\hline & & Total & 124 & 100 \\
\hline
\end{tabular}

\section{Regression Analysis}

The first objective of this study is to determine whether or not the work-family conflict predicts the level of perceived job commitment among employees of Local Government in the Ilesha Metropolis in Osun State. Table 4 shows the regression relationship analysis result between work-family conflict and perceived job performance. The regression analysis shows that $\mathrm{R}=0.637$ and $\mathrm{R}^{2}=0.405$. This means that $40.5 \%$ of the variation in the perceived job performance is explained by a unit change in work-family conflict. F-test was carried out to test the null hypothesis that work-family conflict will not significantly predict perceived job commitment among employees. The ANOVA test shows $\mathrm{F}_{(1,122)}=$ 83.164 and $\mathrm{p}<0.05$, meaning that the null hypothesis is rejected. We can thus conclude that work-family conflict significantly predicts perceived job commitment among employees of Local Government in Ilesha Metropolis in Osun State. 
Table 4: Model Summary and ANOVA Results - Work-Family Conflict and Perceived Job Commitment

\begin{tabular}{clccccc}
\hline & & $\mathrm{R}=0.637$ & & $\mathrm{R}^{2}=0.405$ & \multicolumn{2}{c}{ Adj. $\mathrm{R}^{2}=0.400$} \\
\hline Model & & Sum of Squares & df & Mean Square & F & Sig. \\
1 & Regression & 34.295 & 1 & 34.295 & 83.164 & $.000^{\mathrm{b}}$ \\
& Residual & 50.310 & 122 & .412 & & \\
& Total & 84.605 & 123 & & & \\
\hline
\end{tabular}

a. $\quad$ Dependent Variable: Job Commitment

b. Predictors: (Constant), Work-Family Conflict

Table 5: Coefficient for Relationship between Work-Family Conflict and Perceived Job Commitment

\begin{tabular}{clccccc}
\hline \multirow{2}{*}{ Model } & & \multicolumn{2}{c}{$\begin{array}{c}\text { Unstandardized } \\
\text { Coefficients }\end{array}$} & $\begin{array}{c}\text { Standardized } \\
\text { Coefficients } \\
\text { Beta }\end{array}$ & t & Sig. \\
& & B & Std. Error & Beta & & \\
\hline \multirow{2}{*}{1} & (Constant) & -.722 & .418 & & -1.726 & .087 \\
& Work-Family Conflict & .173 & .019 & .637 & 9.119 & .000 \\
\hline
\end{tabular}

a. Dependent Variable: Job Commitment

Table 5 shows the coefficient for the relationship between work-family conflict and perceived job performance. The results on the beta coefficient of the resulting model in Table $5 \mathrm{~b}$ shows that the constant $\alpha=-0.722$ is not significantly different from 0 since the $\mathrm{p}$-value $=0.087$ is greater than 0.05 . The coefficient $\beta=0.173$ is significantly different from 0 with a $p$-value $=0.000$ which is less than 0.05 . This implies that the null hypothesis $\beta 1=0$ is rejected and the alternative hypothesis $\beta 1 \neq 0$ is taken to imply that the model $\mathrm{Y}=-0.722+0.173$ (work-family conflict) fits better. This confirms that there is a positive linear relationship between work-family conflict and perceived job commitment. The finding of this study concurs with the findings of Lambert, Morrow, Hogan, and Vickovic (2020) who investigated the association between work-family conflict and job involvement among private correctional staff. The study has found that work-family conflict had a positive significant influence on job involvement. However, the findings of this study contradict the submission of Cao, Liu, Wu, Zhao, and Jiang (2020) who reported that work-family conflict interferes with work negatively and significantly affected organizational commitment (Ajibola, 2015; Cao, Liu, Wu, Zhao, \& Jiang, 2020).

The second objective of the study is to evaluate the level at which the job stress predicts the perceived job commitment among employees of Local Government in Ilesha Metropolis. Table 6 shows the regression relationship analysis result between job stress and perceived job performance. The regression analysis shows that $\mathrm{R}=0.560$ and $\mathrm{R}^{2}=0.313$. This meant that $31.3 \%$ of the variation in the perceived job performance is explained by a unit change in job stress. F-test was carried out to test the null hypothesis that job stress will not significantly predict perceived job commitment among employees in Ilesha Metropolis. The ANOVA test shows that $\mathrm{F}_{(1,122)}=55.625$ and $\mathrm{p}<0.05$. This implies that the null hypothesis is rejected and concludes that job stress significantly predicts perceived job commitment among employees of Local Government in the Ilesha Metropolis. 
Table 6: Model Summary and ANOVA Results - Job Stress and Perceived Job Commitment

\begin{tabular}{clccccc}
\hline & & $\mathrm{R}=0.560$ & \multicolumn{2}{c}{$\mathrm{R}^{2}=0.313$} & \multicolumn{2}{c}{ Adj. $\mathrm{R}^{2}=0.308$} \\
Model & & Sum of Squares & Df & Mean Square & F & Sig. \\
\hline \multirow{2}{*}{1} & Regression & 26.495 & 1 & 26.495 & 55.625 & $.000 \mathrm{~b}$ \\
& Residual & 58.110 & 122 & .476 & & \\
& Total & 84.605 & 123 & & & \\
\hline
\end{tabular}

a. Dependent Variable: Job Commitment

b. Predictors: (Constant), Job Stress

Table 7: Coefficient for the relationship between Job Stress conflict and perceived Job Performance

\begin{tabular}{ccccccc}
\hline \multirow{2}{*}{ Model } & & \multicolumn{2}{c}{$\begin{array}{c}\text { Unstandardized } \\
\text { Coefficients }\end{array}$} & $\begin{array}{c}\text { Standardized } \\
\text { Coefficients } \\
\text { Beta }\end{array}$ & t & Sig. \\
& & B & Std. Error & & & \\
\hline \multirow{2}{*}{1} & (Constant) & -.680 & .505 & & -1.347 & .180 \\
& Job Stress & 1.170 & .157 & .560 & 7.458 & .000 \\
\hline
\end{tabular}

a. Dependent Variable: Job Commitment

Table 7 shows the coefficient for the relationship between job stress and perceived job performance. The results on the beta coefficient of the resulting model in Table $6 \mathrm{~b}$ shows that the constant $\alpha=-0.680$ is not significantly different from 0 since the $p$-value $=0.180$ is greater than 0.05 . The coefficient $\beta=$ 1.170 is significantly different from 0 with a $p$-value $=0.000$ which is less than 0.05 . This implies that the null hypothesis $\beta 1=0$ is rejected and the alternative hypothesis $\beta 1 \neq 0$ is taken to hold implying that the model $\mathrm{Y}=-0.680+1.170$ (job stress), is significantly fit. This confirms that there is a positive linear relationship between job stress and perceived job commitment. The finding concurs with some previous studies which have found that there is a significant relationship between job stress and perceived job commitment (John-Akinola, Ajayi, Oluwasanu, 2020; Odor, 2019). They both reported that job stress has a negative significant influence on perceived job commitment.

The third objective of this study is to investigate whether or not self-concept predicts perceived job commitment among the employees of the Ilesha Metropolis in Osun State. Table 8 shows the regressive relationship analysis between self concept and perceived job performance. The regression analysis shows $\mathrm{R}=0.216$ and $\mathrm{R}^{2}=0.047$. This meant only that $4.7 \%$ of the variation in the perceived job performance is explained by a unit change in self-concept. The relationship is weak. as revealed by the result of this study, with the correlation coefficient of $21.6 \%$ between self-concept and perceived job commitment. For specification, F-test was carried out to test the null hypothesis that self-concept will not significantly predict perceived job commitment among the employees. The ANOVA test shows that $\mathrm{F}_{(1,122)}=$ 5.971, and $\mathrm{p}<0.05$. This implies that the null hypothesis is rejected at a $5 \%$ level of significance, since the P-value is less than 0.05 and concludes that self-concept significantly predicts perceived job commitment among the employees.

Table 8: Model Summary and ANOVA Results - Self-Concept and Perceived Job Commitment

\begin{tabular}{|c|c|c|c|c|c|c|}
\hline \multirow[b]{2}{*}{ Model } & \multicolumn{3}{|c|}{$\mathrm{R}=0.216$} & \multirow{2}{*}{$\begin{array}{c}\mathrm{R}^{2}=0.047 \\
\text { Mean Square }\end{array}$} & \multicolumn{2}{|c|}{ Adj. $R^{2}=0.039$} \\
\hline & \multicolumn{2}{|c|}{ Sum of Squares } & df & & $\mathbf{F}$ & Sig. \\
\hline \multirow[t]{3}{*}{1} & Regression & 3.947 & 1 & 3.947 & 5.971 & $.016 \mathrm{~b}$ \\
\hline & Residual & 80.657 & 122 & .661 & & \\
\hline & Total & 84.605 & 123 & & & \\
\hline
\end{tabular}

a. Dependent Variable: Job Commitment

b. Predictors: (Constant), Self-Concept 
Table 9: Coefficient for the relationship between Self-Concept and Perceived Job Performance

Coefficients

\begin{tabular}{clccccc}
\hline Model & & \multicolumn{2}{c}{$\begin{array}{c}\text { Unstandardized } \\
\text { Coefficients }\end{array}$} & $\begin{array}{c}\text { Standardized } \\
\text { Coefficients }\end{array}$ & t & Sig. \\
& B & Std. Error & Beta & & \\
\hline \multirow{2}{*}{1} & (Constant) & 1.858 & .496 & & 3.747 & .000 \\
& Self Concept & .064 & .026 & .216 & 2.444 & .016 \\
\hline
\end{tabular}

a. Dependent Variable: Job Commitment

Table 9 shows the coefficient for the relationship between self-concept and perceived job performance. The results on the beta coefficient of the resulting model in Table $6 \mathrm{~b}$ shows that the constant $\alpha=1.858$ is significantly different from 0 , since the $p$-value $=0.000$ is less than 0.05 . The coefficient $\beta=0.064$ is significantly different from 0 with a $\mathrm{p}$-value $=0.000$, which is less than 0.05 . This implies that the null hypothesis $\beta 1=0$ is rejected and the alternative hypothesis $\beta 1 \neq 0$ is taken, implying that the model $\mathrm{Y}=1.858$ (self-concept), fits significantly better. This confirms that there is a positive linear relationship between self-concept and perceived job commitment. The finding of this study contradicts that of Sinha (2004) but concurs with the findings of Porn (2006) and Kucuk-Yuceyurt and Yilmaz (2020). Sinha (2004) found that self-concept does not influence perceived job commitment. However, Porn (2006) and Kucuk-Yuceyurt and Yilmaz (2020) reported a positive association between self-concept, job satisfaction and job commitment.

\section{Discussion}

The result revealed that self-concept, work-family conflict and job stress independently predict perceived job commitment among the employees of Local Government authority in the Ilesha metropolis of Osun State. The findings of this study concur with the findings of Lambert, Morrow, Hogan, and Vickovic (2020) who investigated the association between work-family conflict and job involvement among private correctional staff. The study has found that work-family conflict had a positive significant influence on job involvement. However, the finding of this study contradicts the submission of Cao, Liu, Wu, Zhao, and Jiang (2020) who reported that work-family conflict interferes with work negatively and significantly affected organizational commitment (Ajibola, 2015; Cao, Liu, Wu, Zhao, \& Jiang, 2020). The findings of this study also contradict the findings of Zain and Setiawati (2019) who reported that work-family conflict (WFC) had no significant influence on organizational commitment.

Though the amount of WFC continues to be moderate among workers in Ilesha Metropolis, it doesn't rule out the very fact that the experience exists. This is in agreement with the findings of Cao, Liu, $\mathrm{Wu}$, Zhao, and Jiang (2020) who found that WFC increasingly and adversely affected employee job performance. The findings of this study also corroborate that of Greenhaus and Powell (2010), who reported that holding multiple roles within the work and family domains also yields positive outcomes. This study shows that when employees are faced with incessant conflicts of interest between work and family it ends up in job turnover. This case is inimical to the organizational output as a result of its effect on employees' job performance.

Furthermore, the finding of this study concurs with some previous studies which have found that there is a significant relationship between job stress and perceived job commitment (John-Akinola, Ajayi, Oluwasanu, 2020; Odor, 2019). They both reported that job stress has a negative significant influence on perceived job commitment. It also revealed that authority workers in Ilesha Metropolis experienced moderate job stress. They faced problems through stressors that have been discussed in the study, like extremely hot working environments, inadequacy of office lighting and furniture lack of 
apparatus to complete one's work, and problems as such. This assertion is in agreement with the claims of Ivancevich and Matterson (1980) who state that stress is the consequence of environmental action, situation, or event.

Since the identified stressors are environmental, it is easy to identify them among the authority workers in the Ilesha Metropolis. The findings also show a significant relationship between job stress and employee job performance. This is in agreement with the assertion of Hansen (2008), who had also found that stress is a significant predictor of employee job performance. This study shows that when employees are stressed out because of job demands, it results in them committing errors and getting unsatisfactory job performance, which could lead to termination of appointment and labor turnover. Such an outcome is detrimental to the course of organizational effectiveness.

Lastly, the finding of this study concurs with the findings of Porn (2006) and Kucuk-Yuceyurt and Yilmaz (2020), but disagrees with the findings of Sinha, (2004) who found that self-concept does not influence perceived job commitment. However, Porn (2006) and Kucuk-Yuceyurt and Yilmaz (2020) reported a positive association between self-concept and job satisfaction and job commitment. The findings of this study conform to the findings of the previous researches that found that components of a positive self-concept construct were among the most effective predictors of job performance (Judge, Thoresen, Bono, and Patton, 2001; Lambert, Morrow, Hogan, \& Vickovic, 2020).

\section{Conclusion}

The study has investigated the antecedents of employee perceived job commitment among Local Government employees in Ilesha Metropolis. The self-concept, work-family conflict, and job stress were used to proxy antecedents in the study. The study found that antecedents of job commitment (selfconcept, work-family conflict, and job stress) independently predict perceived job commitment among employees of Local Government authority in the Ilesha metropolis of Osun State of Nigeria. From the results, it was concluded that there exist self-concept, work-family conflict and job concept among the Local Government employees in the Ilesha metropolis which explains their perceived job commitment. The study also established that self-concept, work-family conflict and job stress significantly predicts the perceived job performance of Local Government employee in Ilesha Metropolis. On the general analysis, the self-concept of the Local Government employees in the Ilesha metropolis was found to be high; the work-family conflict was low with moderate job stress.

Based on the findings of the study the following recommendations were made. The government should adopt a welfare approach in tackling family-related issues that have to do with Local Government employees' which have a direct bearing on employee job commitment. It is also recommended that management policies should include welfare packages and improve current compensation packages that can promote a high level of job satisfaction to enhance the level of employee job commitment. The study further recommended that federal government and Local Government authorities should engage the services of experts in the areas of human resource management, industrial and organization psychology from time to time. It is considered important to convey talks on stress management and self-concept with a view of converting the later to high employee job commitment of the Local Government employees. In view of the findings of this study, certain areas of focus like HR demographic characteristics, gender aspect of job stress, families living with children in the domain of WFC, and their influence on organizational outcomes such as employee commitment, engagement, and organizational effectiveness are suggested for further study.

\section{Conflict of Interest}

No conflict of interest is declared in this paper. 


\section{References}

Abasilim, U. D., Gberevbie, D. E., \& Osibanjo, O. A. (2019). Leadership styles and employees' commitment: empirical evidence from Nigeria. SAGE Open. https://doi.org/10.1177/2158244019866287

Abiodun, T. (2013). We are no longer Osomaalo. The Nations Newspaper. Lagos: The Nations Newspaper. Retrieved July 23, 2020, from https://thenationonlineng.net/longer-osomaalo/

Aboobaker, N., \& Edward, M. (2019). Collective influence of work-family conflict and work-family enrichment on turnover intention: Exploring the moderating effects of individual differences. Global Business Review. https://doi.org/10.1177/0972150919857015

Afshari, L. (2020). Motivating toward organizational commitment: A cross-comparative perspective. International Journal of Cross Cultural Management. https://doi.org/10.1177/1470595820914643

Ajibola, K. S. (2015). Influence of time management on employees' commitment to the organization: A case study of the University of Lagos. Unpublished Master project, University of Lagos, Lagos, Nigeria.

Allen, J. N. \& Meyer, J. P. (1990). The measurement and antecedents of affective, continuance, and normative commitment to the organization. Journal of Occupational Psychology, 63 (1), 1-18.

Altura, T. G., Rao, A. N., \& Virick, M. (2020). Proactive personality as a double-edged sword: The mediating role of work-family conflict on employee outcomes. Journal of Career Development. https://doi. org/10.1177/0894845319899984

Babbie, E. R. (2016). The Practice of Social Research (14th ed.). Boston, MA: Cengage Learning.

Badawy, P. J., \& Schieman, S. (2020). When family calls: How gender, money, and care shape the relationship between family contact and family-to-work conflict. Journal of Family Issues, 41(8), 1188-1213. https:// doi.org/10.1177/0192513X19888769

Balogun, A. G., \& Afolabi, O. A. (2019). Examining the moderating roles of job demands and resources on the relation between work engagement and work-family conflict. South African Journal of Psychology, 49(4), 479-490. https://doi.org/10.1177/0081246318818382

Bryer, A. (2020). Making organizations more inclusive: The work of belonging. Organization Studies, 41(5), 641-660. https://doi.org/10.1177/0170840618814576

Cao, J., Liu, C., Wu, G., Zhao, X. \& Jiang, Z. (2020). Work-family conflict and job outcomes for construction professionals: The mediating role of affective organizational commitment. International Journal of Environmental Research and Public Health, 17(4), 1443 2-24.

Chanda, U. \& Goyal, P. (2019). A Bayesian network model on the interlinkage between Socially Responsible HRM, employee satisfaction, employee commitment, and organizational performance. Journal of Management Analytics, 1-22. DOI: 10.1080/23270012.2019.1650670

Chrisangika Perera, J. K. S., \& Kailasapathy, P. (2020). Individual, spousal factors, and work-family conflict: A study from Sri Lanka. South Asian Journal of Human Resources Management, 7(1), 91-120. https://doi. org/10.1177/2322093720923276

Deng, J., Guo, Y., Ma, T., Yang, T., \& Tian, X. (2019). How job stress influences job performance among Chinese healthcare workers: a cross-sectional study. Environmental Health and Preventive Medicine, 24(2). https:// doi.org/10.1186/s12199-018-0758-4.

Dolson, J. M., \& Deemer, E. D. (2020). The relationship between perceived discrimination and school/ work-family conflict among graduate student-parents. Journal of Career Development. https://doi. org/10.1177/0894845320916245

Dubrin, A. J. (1997). Fundamentals of Organizational Behaviour. Cincinnati, OH: Southwestern College Publishing.

Ellis, S., \& Dick, D. (2003). Introduction to organizational behaviour, (2nd ed.), New York, NY: McGraw- Hill Education.

Erikson, E. H. (1959). Identity and the life cycle. New York, NY: International Universities Press.

Gamble, T. K. \& Gamble, M. (2002). Communication works. In rupert tripp. Interpersonal communication and self-concept. Journal of Academic Writing, 5, 52-68. 
Greenhaus, J. H. \& Beutell, N. J. (1985). Sources of conflict between work and family roles. Academy of Management Review, 10, 76-88.

Greenhaus, J. H. \& Powell, G. N. (2010). When work and family are allies: a theory of work-family enrichment. Academy of Management Review, 31, 72- 92.

Haines, V. Y., Bilodeau, J., Demers, A., Marchand, A., Beauregard, N., Durand, P., \& Blanc, M.-E. (2019). Sex, gender dynamics, differential exposure, and work-family conflict. Journal of Family Issues, 40(2), 215239. https://doi.org/10.1177/0192513X18806945

Hansen, A. (2008). Factors affecting hospital nurses Riyadh region, Saudi Arabia. International Journal of Health Care Quality Assurance. 22(1), 40- 54.

Hur, H., \& Perry, J. L. (2019). Job security rule changes and employee organizational commitment. Review of Public Personnel Administration. https://doi.org/10.1177/0734371X19842622

Ivancevich, J. M. \& Matteson, M. T. (1980). Stress and work: A managerial perspective. Glenview, IL: Scott Foresman

Izogo, E. E., Elom, M. E., \& Mpinganjira, M. (2020). Examining customer willingness to pay more for banking services: the role of employee commitment, customer involvement, and customer value. International Journal of Emerging Markets, ahead-of-print (ahead-of-print). https://doi.org/10.1108/ IJOEM-10-2019-0850.

John-Akinola, Y. O., Ajayi, A. O., \& Oluwasanu, M. M. (2020). Experience of stress and coping mechanism among police officers in South-Western Nigeria. International Quarterly of Community Health Education. https://doi.org/10.1177/0272684X19900878

Judge, T.A., Thoresen, C. J., Bono, J. E. \& Patton, G. K. (2001). The job satisfaction - job performance relationship: A qualitative and quantitative review. Psychological Bulletin, 376- 407.

Kahn, R. L., Wolfe, D. M., Quinn, R. P., Snoek, J. D., \& Rosenthal, R. A. (1964). Organizational stress: Studies in role conflict and ambiguity. New York, NY: Wiley

Kaufman, G., \& Taniguchi, H. (2019). Gender equality and work-family conflict from a cross-national perspective. International Journal of Comparative Sociology, 60(6), 385-408. https://doi. org/10.1177/0020715219893750

Khalid, K. (2020). The impact of managerial support on the association between pay satisfaction, continuance, and affective commitment, and employee task performance. SAGE Open. https://doi. org/10.1177/2158244020914591

Kroll, A., DeHart-Davis, L., \& Vogel, D. (2019). Mechanisms of social capital in organizations: How team cognition influences employee commitment and engagement. The American Review of Public Administration, 49(7), 777-791. https://doi.org/10.1177/0275074019851894

Kucuk-Yuceyurt, N., \& Yilmaz, M. (2020). Professional self-concept and job satisfaction among nurses in psychiatric clinics. Progress in Health Sciences, 10(1), in press.

Lambert, E. G., Morrow, W., Hogan, N. L., \& Vickovic, S. G. (2020). Exploring the association between workfamily conflict and job involvement among private correctional staff. Journal of Applied Security Research, 15(1), 49-72.

Lee, E., \& Jang, I. (2020). Nurses' fatigue, job stress, organizational culture, and turnover intention: A culture-work-health model. Western Journal of Nursing Research, 42(2), 108-116. https://doi. org/10.1177/0193945919839189

Lizote, S. A., Verdinelli, M. A., \& do Nascimento, S. (2017). Organizational commitment and job satisfaction: A study with municipal civil servants. Brazilian Journal Public Administration, 51(6), 947-967.

MacKinnon, N. J., \& Heise, D. R. (2010). Self, identity, and social institutions. New York: Palgrave Macmillan.

Marchiori, D. \& Henkin, A. (2004). Organizational commitment of health profession faculty: Dimensions, correlates, and conditions. Medical Teacher, 26(4), 353.

Meyer, J. P., Stanley, D. J., Herscovitch, L. \& Topolnytsky, L. (2002). Affective, continuance, and normative commitment to the organization: A meta-analysis of antecedents, correlates and consequences. Journal of Vocational Behaviour, 61(1), 20-52. 
Narisada, A. (2020). Job pressure, the work-family interface, and the sense of distributive injustice: an elaboration of work-related inputs among twenty-first century workers. Social Psychology Quarterly, 83(2), 107-128. https://doi.org/10.1177/0190272519874294

Nwekpa, K. C., Offor, P. G., Ezezue, B. O. (2020). Work schedule flexibility and employee commitment: a study of Nigerian Breweries, Ama, Enugu, Nigeria. International Journal of Development and Management Review (INJODEMAR), 15( 1), 1-16.

Odor, H. O. (2019). Work-related stress and employee commitment at Delta State Polytechnic, Ogwashi Uku, Delta State of Nigeria. Global Journal Of Management And Business Research,19(1-A). Retrieved from https://www.journalofbusiness.org/index.php/GJMBR/article/view/2679

Owens, T. J., \& Samblanet, S. (2013). Self and self-concept. In J. DeLamater, \& A. Ward (Eds.). Handbook of Social Psychology (pp. 225-249). London: Springer Science.

Paillé, P., \& Valéau, P. (2020). I don't owe you, but I am committed: does felt obligation matter on the effect of green training on employee environmental commitment? Organization \& Environment. https://doi. org/10.1177/1086026620921453

Purkey, W. (1998). An overview of self-concept theory for counsellors. Retrieved January 3, 2020, from http:// www.aare.edu.au/05pap/hau05333.pdf

Rosenberg, M. (1979). Conceiving the self. Malabar, FL: Krieger Publishing.

Roy, D., Weyman, A. K., Plugor, R., \& Nolan, P. (2020). Institutional commitment and aging among allied health care professionals in the British National Health Service. Health Services Management Research. https:// doi.org/10.1177/0951484820918513

Schultz, D. P. \& Schultz, S. E. (2017). Theories of Personality (11th ed.). Boston, MA: Cengage Learning.

Shavelson, R. J., Hubner, J. J., \& Stanton G. C. (1976). Self-concept: Validation of construct interpretations. Review of Educational Research, 46(3), 407- 441. DOI:10.3102/00346543046003407.

Tripp, R. (2003). Interpersonal communication and self-concept. Journal of Academic Writing, 6, 95-105.

Tuffour, J. K., Gali, A. M., \& Tuffour, M. K. (2019). Managerial leadership style and employee commitment: Evidence from the financial sector. Global Business Review. https://doi.org/10.1177/0972150919874170

Vickovic, S. G., \& Morrow, W. J. (2020). Examining the influence of work-family conflict on job stress, job satisfaction, and organizational commitment among correctional officers. Criminal Justice Review, 45(1), 5-25. https://doi.org/10.1177/0734016819863099

Wang, Q., Weng, Q. (Derek), \& Jiang, Y. (2020). When does affective organizational commitment lead to job performance?: Integration of resource perspective. Journal of Career Development, 47(4), 380-393. https://doi.org/10.1177/0894845318807581

Yahaya, Z. S. (2020). Employee inclusion during change: The stories of middle managers in non-profit home care organizations. Home Health Care Management \& Practice, 32(3), 165-171. https://doi. org/10.1177/1084822320901442

Yamane, T. (1967). Statistics: An Introductory Analysis, (2nd ed.). New York: Harper and Row.

Zain, A. N. D., \& Setiawati, T. (2019). Influence of work-family conflict and job satisfaction on medical employee performance through organizational commitment. Review of Integrative Business and Economics Research, 8(1), 1-19. 